\author{
Ivan Turudić, Univ. Spec. Crim. \\ County Court of Zagreb \\ Trg N. Š. Zrinskog 5, Zagreb, Croatia \\ ivan.turudic@zszg.pravosudje.hr
}

\title{
CASE LAW ON THE EUROPEAN ARREST WARRANT
}

\begin{abstract}
The paper deals with the European arrest warrant in the case law of Croatian courts and presents the principles of mutual recognition and trust, as well as the principle of the verification of double criminality which has attracted a lot of attention in professional circles in the area of international judicial cooperation in criminal matters. The introductory part of the paper addresses the importance of this instrument as the cornerstone of judicial cooperation in criminal matters between EU Member States. This is followed by an analysis of the fundamental principles, specifically the principle of mutual trust as a structural principle of EU constitutional law, its origin and context in the light of the decisions rendered by the Supreme Court of the Republic of Croatia and the Constitutional Court of the Republic of Croatia. The central part of the paper analyses the principle of verification of double criminality and the implementation of that principle in the process of executing the European arrest warrant, and relates that principle to the mandatory and optional grounds for non-execution of the warrant. A brief overview is then provided of the execution of the warrant with reference to the decisions of the Supreme Court of the Republic of Croatia, and the paper ends with an evaluation of the significance of the principle of mutual recognition in criminal matters as exemplified by the judgments of the Court of Justice of the European Union.
\end{abstract}

Keywords: European arrest warrant, mutual trust, mutual recognition, double criminality

\section{INTRODUCTION}

The European arrest warrant is an arrest warrant issued by the competent judicial body of a Member State of the European Union (hereafter: EU) for the arrest and surrender of a person who happens to be in another Member State, with a view to prosecution or execution of a custodial sentence or a detention order. The purpose of the European arrest warrant is to create a quick, efficient and effective judicial cooperation between EU Member States in the suppression and deterrence of crime. Judicial cooperation in criminal matters between EU Member States must involve such mutual trust and surrender of persons requested by another Member 
State that supersedes state sovereignty and allows all Member States to effectively combat serious crime. ${ }^{1}$

However, given the sensitivity of all States about the surrender of their own citizens and their initial caution with regard to accepting the Framework Decision on the European arrest warrant and the surrender procedures between Member States ${ }^{2}$, the process of implementation of the Framework Decision, pursuant to Article 32, allowed each Member State to, once the Council has adopted the Framework Decision, make a statement indicating that as executing Member State it would continue to deal with requests relating to acts committed before a date which it specifies in accordance with the extradition system applicable before 1 January 2004. Some member States have thus placed a time restriction on the application of the European arrest warrant, and such statements have been issued by: the Czech Republic in respect of its citizens who committed crimes before 1 November 2004, the Republic of Austria and Luxembourg for crimes committed before 7 August 2002, France for crimes committed before 1 November 1993 (related to the entry into force of the Treaty on European Union) and Italy for crimes committed before 1 August 2002 (but executing those warrants issued before 14 May 2005).

Since the option of making the statement about placing a time restriction on the application of the European arrest warrant existed only at the time the the Framework Decision was being adopted by the Council, and given the fact that during accession negotiations the Republic of Croatia had not requested that such time restriction be placed on the application of the warrant, the Act on Judicial Cooperation in Criminal Matters with Member States of the European Union (hereafter: AJCCM-EU), which did contain a time restriction, was amended in the way that Article 132(3) reading „The European arrest warrant shall be executed in respect of the crimes committed after 7 August 2002" was deleted. ${ }^{3}$

In accordance with that, European arrest warrants are also issues retroactively in the Republic of Croatia for crimes committed before the coming into force of AJCCM-EU and Croatia's accession to the European Union. ${ }^{4}$

1 Turudić, I., Pavelin Borzić, T., Bujas, I., European arrest warrant with examples from case law, Novi Informator, Zagreb, 2014, p. 13

2 Council Framework Decision 2002/584/JHA on the European arrest warrant $t$ and the surrender procedures between Member States [2002] OJ L 190/1

3 Turudić, I., Pavelin Borzić, T., Bujas, I. The Impact of the Framework Decision on the European Arrest Warrant on the Constitutional Order of Member States (part 1), Novi informator, no.6285/2014, p. 2

4 For more on the reasons for amendments to AJCCM-EU see: Krapac, D., Framework Decision of the Council [of the European Union] of 13 June 2002 on the European (EUN) and the surrender procedures 


\section{FUNDAMENTAL PRINCIPLES OF JUDICIAL COOPERATION}

In the preamble to the Framework Decision it is pointed out that the European arrest warrant is the first concrete measure in the field of criminal law implementing the principle of mutual recognition, that the mechanism of the European arrest warrant is based on a high level of confidence between Member States, and that its implementation may be suspended only in the event of a serious and persistent breach by one of the Member States of the principles set out in Article 6(1) of the Treaty on European Union.

The origin and context of the prinicple of mutual confidence is manifest in the principle of mutual recognition as a method of cooperation and integration in the area of freedom, security and justice. ${ }^{5}$ The principle of mutual recognition presupposes and derives from the principle of mutual confidence, which is also pointed out by the Court of Justice of the European Union in the Court's decision Jeremy F. $v$ Premier ministre ${ }^{6}$ which reads as follows: "The principle of mutual recognition on which the European arrest warrant system is based is itself founded on the mutual confidence between the Member States that their national legal systems are capable of providing equivalent and effective protection of the fundamental rights recognized at European Union level, particularly in the Charter, so that it is therefore within the legal system of the issuing Member State that persons who are the subject of a European arrest warrant can avail themselves of any remedies which allow the lawfulness of the criminal proceedings for the enforcement of the custodial sentence or detention order, or indeed the substantive criminal proceedings which led to that sentence or order, to be contested." 7

As regards the Republic of Croatia, the principles the domestic courts should be guided by in judicial cooperation in criminal matters with EU Member States are found in decision No. U-III-351/2014 of the Constitutional Court of the Republic of Croatia of 24 January 2014 wherby the Constitutional Court decided on the consitutional complaint alleging violations of human rights and fundamental freedoms guaranteed under the Constitution of the Republic of Croatia, which violations were, according to the complainant, committed in the process of surrender based on the European arrest warrant under order No. Kv-eun-2/14 of the

between Member States (2002/584/JHA), Collected Papers of the Law Faculty of Zagreb, 64(5-6), p. 960

5 For more on the development of the principle of mutual confidence see:

[www.ejtn.eu/.../THEMIS\%20written\%20paper\%20-\%20Romania...] Accessed 1 March 2018

$6 \quad$ Case C-168/13 Jeremy F. v Premier ministre [2013] OJ C 156, par. 50

7 Turudić, I., Pavelin Borzić, T., Bujas, I., Relationship Between the Principles of Mutual Recognition/Confidence and Verification of Double Criminality, Collected Papers of the Law Faculty of the University of Rijeka, 36(2), p. 1081 
County Court of Zagreb of 8 January 2014 and order No. Kž-eun-2/14 of the Supreme Court of 17 January 2014. The relevant decision of the Constitutional Court affirmed the Supreme Court of the Republic of Croiatia as the supreme authority on statutory interpretation. The lawmakers have thus been precluded from influencing court decisions in concrete cases by frequent amendments to legislation, given that national courts are under a duty to interpret laws in accordance with the EU acquis communautaire, the principle of the effective judicial cooperation in criminal matters and loyalty, and in the light of the principle of mutual recognition. Thus, the Constitutional Court of the Republic of Croatia bound the national courts to construe domestic legislation in the light of the decision of the Court of Justice of the European Union in the case Pupino. ${ }^{8}$

The relevant part of the cited decision of the Constitutional Court of the Republic of Croatia reads as follows:

"10. Framework Decision 2002/584, which in its preamble invokes the principle of mutual recognition of judgments and judicial decisions in criminal matters (item 10, first sentence of the preamble) and replaces the previous instruments providing for „classical“ extradition between Member States, must be implemented in domestic law in the way that contributes to the realisation of the principle of mutual recognition of the Member States' judicial decisions and in that way creates a cross-border common area of criminal law for the application of national criminal laws and national jurisdiction of the criminal courts of EU Member States.

In that context, it is sufficient to recall that, even before the Treaty of Lisbon took effect on 1 December 2009, the Court of Justice of the European Union, in its judgment C-105/03 - Pupino (Criminal proceedings against Maria Pupino [2005] ECR I-5285) given by the Grand Chamber on 16 June 2005, had expanded the doctrine of indirect effect of Community law to apply to framework decisions, too, by establishing the loyalty principle as the basis for the obligation of conformity of interpretation.

Neverheless, due to the diversity in the legal orders of EU Member States in the area of criminal law, their cultural and social differences as well as the different underlying criminal law doctrines, surrender is an institution still in the process of being developed, which leads to potential differences in the approach adopted by individual EU Member States in respect of the normative framework for transposing Framework Decision 2002/584 and the interpretation of surrender in the light of the principle of mutual recognition (as the cornerstone in creating an

Turudić et al., op. cit. note 7, p. 1093 
area of freedom, security and justice based on a high level of confidence between member States), the principle of subsidiarity and the principle of proportionality.

11. In light of that, the Constitutiona Court recalls that the procedure involving the surrender of a Croatian citizen to another EU Member State is not a criminal procedure, but rather a judicial procedure sui generis aimed at enabling criminal prosecution or enforcement of a penal judgment to take place in another EU Member State, and not aimed at deciding on the guilt of a criminal suspect or punishment for the committed offence.

It follows that judicial decisions made in that procedure are subject to constitutional review only in respect of a narrow range of potential violations involving exclusively human rights and fundamental freedoms guaranteed under the Constitution (i.e. constitutional rights).

Consequently, the Constitutional Court is competent to assess, for instance, whether the requested person faces in the requesting Member State the risk of torture or inhuman or degrading process or punishment. ...

In addition, the Constitutional Court is competent to examine, for instance, whether there is a real risk that the requested person (a Croatian citizen) might, in the Member State that issued the European arrest warrant, suffer a flagrant denial of a fair trial in the way that would negate the very essence of his or her right to a fair trial. Until the Court of Justice of the European Union potentially sets a different benchmark, the Constitutional Court shall be guided by the meaning of "a flagrant denial of a fair trial" as defined by the European Court of Human Rights in the case Ahorugeze v. Sweden (judgment of 27 October 2011, application no. 37075/09, \$ 114-115) ...

Finally, as regards the procedure before domestic courts in the execution of the European arrest warrant, the Constitutional Court is competent to examine whether the assessment of the domestic courts deciding on surrender was "flagrantly and manifestly arbitrary" to the extent that allowed a Croatian citizen to be surrendered to another Member State in contravention of Article 9(2) of the Constitution."

The principles underlying any decision on the execution of the European arrest warrant are also analysed in decision No. Kž-eun 12/17 of the Supreme Court of the Republic of Croatia of 7 March 2017, which reads as follows:

"It is worth pointing out that the European arrest warrant is an instrument of mutual cooperation between EU Member States founded on the principles of mutual recognition (AJCCM-EU, Article 3) and effective cooperation (AJCCM- 
EU, Article 4) between the Member States, and that it consequently imposes on the national courts of the executing States a legal obligation and moral responsibility to approve the surrender of a requested person, save in the case of the rare and expressly prescribed grounds for refusing surrender. Among other possible grounds for refusing execution of the European arrest warrant, Article 20(2)(2) of AJCCM-EU provides for the situation where it has come to the court's attention that the requested person has already been finally convicted in respect of the charged offence in another Member State, provided that the penal sanction has already been executed, or is in the process of being executed, or can no longer be executed under the law of the country in which the judgment was rendered. From the submitted documentation on which the requested person's appeal is founded, not only is it not apparent that A.B. has already been finally convicted in respect of the same offences, but the very claim made by the appellant about the 54 days he spent in detention negates the existence of the statutory bar prescribed under Article 20(2)(2) of AJCCM-EU, which is met only where a penal sanction has been executed, or is in the process of being executed, or can no longer be executed under the law of the country that rendered the judgment, none of which is obviously the case in the instant case."

The same is apparent from the decision of the Supreme Court of the Republic of Croatia No. Kž-eun-5/14 of 6 March 2014:

"...Thereore, in order to achieve the objectives and comply with the principles set out in EU law, national courts are under a duty to apply national law in the light o the letter and the spirit o EU legislation. This means that national law must in its application to the highest possible extent be interpreted in the light of the wording and purpose of the relevant framework decisions and directives, with a view to producing the result the framework decisions and directives strive to achieve, and to complying with Article 34(2.b.) of the Treaty on European Union (which is expressly stated in the judgment given by the European Court o Justice on 16 June 2005 in case no. C-105/03 P). By acceding to the European Union, the Republic of Croatia undertook to act along those lines."

\section{DOUBLE CRIMINALITY}

The transposition of the Framework Decision on the European arrest warrant into EU Member States' national legislation called for amending the constitutional guarantees, inter alia the one that had for ages been part of the countries' domestic legal orders - the possibility of refusing to extradite one's own citizens. 
Besides that, the European arrest warrant excludes the verification of double criminality for 32 categories of criminal offence, ${ }^{9}$ provided that the offences are punishable in the issuing Member State by a custodial sentence or a detention order for a maximum period of at least three years, which makes the warrant an instrument that, besides requiring Member States to extradite their own nationals, also demands extradition for an offence that under the Member States' legislation does not amount to a criminal offence at all so that there are no impediments to extradition on account of a financial element of the offence. ${ }^{10}$

In respect of offences that are not encompassed by one of the categories for which the verification of double criminality is excluded, the condition for execution of the European arrest warrant is that the relevant crime constitutes a punishable offence under the national law of the executing country, too, provided that it carries a custodial penalty of at least four months. ${ }^{11}$

The condition regarding the prescribed custodial sentence of at least one year for offences for which double criminality must be verified, and at least three years for those for which no verification of double criminality is required, must be fulfilled only in the country issuing the European arrest warrant, and not in the excuting country, as is apparent from the Judgment Openbaar Ministerie v A. , ${ }^{12}$ whose relevant part reads:

9 The list reads: participation in a criminal organisation, terrorism, trafficking in human beings, sexual exploitation of children and child pornography, illicit trafficking in narcotic drugs and psychotropic substances, illicit trafficking in weapons, munitions and explosives, corruption, fraud, including that affecting the financial interests of the European Communities within the meaning of the Convention of 26 July 1995 on the protection of the European Communities' financial interests, laundering of the proceeds of crime, counterfeiting currency, including of the euro, computer-related crime, environmental crime, including illicit trafficking in endangered animal species and in endangered plant species and varieties, facilitation of unauthorised entry and residence, murder, grievous bodily injury, illicit trade in human organs and tissue, kidnapping, illegal restraint and hostage-taking, racism and xenophobia, organised or armed robbery, illicit trafficking in cultural goods, including antiques and works of art, swindling, racketeering and extortion, counterfeiting and piracy of products, forgery of administrative documents and trafficking therein, forgery of means of payment, illicit trafficking in hormonal substances and other growth promoters, illicit trafficking in nuclear or radioactive materials, trafficking in stolen vehicles, rape, arson, crimes within the jurisdiction of the International Criminal Court, unlawful seizure of aircraft/ships, sabotage

10 Turudić, et al., op. cit. note 3, p. 2

11 Where the European arrest warrant is issued in respect of an offence punishable by custodial life sentence or lifetime detention, the court may make its execution subject to the condition that 1 ) there is a statutorily prescribed possibility for the imposed penalty or sanction to be reviewed in the issuing country at the request of the convict or ex officio not later than 20 years from the sanction being imposed, and 2) the convicted person has the right to apply for pardon from further serving his or her sentence or sanction in accordance with the law or case law of the issuing country

12 Case C-463/15 Openbaar Ministerie v. A. [2015] OJ C 38 
"\$27 Moreover, neither Article 2(4) and Article 4.1 of Framework Decision 2002/584 nor any other provisions thereof provide for the possibility of opposing the execution of a European arrest warrant concerning an act which, while constituting an offence in the executing Member State, is not there punishable by a custodial sentence of a maximum of at least twelve months.

$\$ 28$ This finding is corroborated by the general background of Framework Decision 2002/584 and by the objectives that it pursues.

$\$ 29$ As is clear from the first two paragraphs of Article 2, this Framework Decision focuses, with regard to offences in respect of which a European arrest warrant may be issued, on the level of punishment applicable in the issuing Member State (see, to that effect, the judgment in Advocaten voor de Wereld, C303/05, EU:C:2007:261, paragraph 52). The reason for this is that criminal prosecutions or the execution of a custodial sentence or detention order for which such a warrant is issued are conducted in accordance with the rules of that Member State.

$\$ 30$ In contrast to the extradition regime which it removed and replaced by a system of surrender between judicial authorities, Framework Decision 2002/584 no longer takes account of the levels of punishments applicable in the executing Member States. This corresponds to the primary objective of this Framework Decision, referred to in recital 5 in its preamble, of ensuring free movement of judicial decisions in criminal matters, within an area of freedom, security and justice.

$\$ 31$ It follows from all of the foregoing considerations that Article 2(4) and Article 4.1 of Framework Decision 2002/584 must be interpreted as precluding a situation in which surrender pursuant to a European arrest warrant is subject, in the executing Member State, not only to the condition that the act for which the arrest warrant was issued constitutes an offence under the law of that Member State, but also to the condition that it is, under that same law, punishable by a custodial sentence of a maximum of at least twelve months."

AJCCM-EU in Article 20(1) defines the requirement of double criminality as being met where "the offence contains the same essential elements under domestic legislation, too, irrespective of the statutory description and the legal designation of the punishable act indicated in the issued warrant", and Article 2(4) of the Framework Decision provides that " the requested person may be surrendered subject to the condition that the acts for which the European arrest warrant has been issued constitute an offence under the law of the executing Member State, whatever the constituent elements or however it is described." 
In addition, in deciding on the execution of the European arrest warrant, the courts establish whether formal requirements for issuing the European arrest warrant existed in the first place, and whether mandatory or optional grounds exist for refusing execution, whereas the merits of the factual and legal description of the act indicated in the warrant are not ascertained at all, as is apparent, inter alia, from decision No. Kž-eun 22/17 rendered by the Supreme Court of the Republic of Croatia on 31 August 2017:

"The appellant disputes the existence of reasonable grounds to believe that he committed the offence alleged in the warrant and submits that 'he should have been given an oportunity to plead in respect of the facts, by being summoned, etc.)'. Given that detention is involved, and that the requested person has never received a summons or a warrant in Germany and has consequently been denied participation in the proceedings, the grounds for refusing execution of the warrant as set out in Article 21(2) of AJCCM-EU do exist.

Contrary to the allegations made by the appellant, the first-instance court acted properly in finding, after having conducted the proceedings and questioned the requested person, that all statutory requirements set out in Article 29 of AJCCMEU had been met for surrendering D.T., despite his opposition, to the Federal Republic of Germany, in order for criminal proceedings to be conducted for the offence described in the warrant. This second-instance court does not find acceptable the appellant's claim that there are no reasonable grounds for believing that he committed the charged offence. Namely, it is not for this court in this proceeding to establish whether the factual and legal description of the charged offence are well founded; rather, the court's task is to assess whether the requirements for surrendering the requested person have been met, and whether there may be grounds for refusing surrender as prescribed in Articles 20 and 21 of the cited Act. Since the appellant's objection is of a factual nature, it is exclusively up to the court of the country that issued the warrant to decide on it after conducting a comprehensive proceeding and hearing all the necessary evidence."

Mandatory and optional grounds for refusing execution of the warrant are set out in Article 20 and 21 of AJCCM-EU. Where mandatory grounds exist, the court must refuse to execute the warrant, and where there are optional grounds it may, following the principles of effective cooperation, expediency and the right to a fair trial, refuse to execute the warrant. The court must refuse execution of the European arrest warrant where: 1) the European arrest warrant was issued for an offence covered by amnesty in the Republic of Croatia, and the domestic court is vested with jurisdiction under the law; 2) the court is informed that the requested person has already been finally convicted in a Member State in respect of the same 
offence, subject to the condition that the penal sanction has been executed, or is in the process of being executed, or can no longer be executed under the law of the country in which the judgment was rendered; 3 ) at the time the offence was committed, the requested person was below the age of 14; 4) the offence from Article $17(2)$ of this Act, to which the European arrest warrant pertains, does not constitute a criminal offence under domestic law (for fiscal offences, the execution of an EAW may not be refused on the ground that the law of the executing Member State does not impose the same kind of tax or duty or does not contain the same type of rules as regards taxes, duties and customs and exchange regulations as the law of the issuing Member State); 5) criminal proceedings against the requested person are pending in the Republic of Croatia on charges of having committed the same offence as that charged in the EAW, save where the state attorney and the competent authority of the issuing Member State have agreed that the proceeding will be conducted by the judicial body of the issuing State; 6) the domestic judicial body has decided not to bring criminal proceedings for the offence charged in the EAW on the grounds that the suspect has fulfilled the obligations imposed on him or her as a condition for non-institution of such proceedings; 7) criminal prosecution or the execution of a penal sanction has become statute-barred, and the Republic of Croatia has jurisdiction under domestic law; 8) the court is informed that the requested person has already been finally convicted in respect of the same offence in a third country, and the sanction has been executed, or is in the process of being executed, or can no longer be executed under the law of the country in which the judgment was rendered. The court may refuse to execute the EAW where: 1) the domestic judicial authority has decided not to bring criminal proceedings for an offence in respect of which the EAW has been issued, or criminal proceedings have been discontinued, or a final judgment has been given against the requested person in a Member State for the same offence; 2) the EAW pertains to offences which: a) were in whole or in part committed in the territory of the Republic of Croatia, b) were committed outside of the issuing country's territory, and domestic law does not allow such offences to be prosecuted when they are committed outside of the territory of the Republic of Croatia. ${ }^{13}$

13 The Framework Decision provides for three cases where non-execution of the EAW is mandatory: amnesty (if the offence in respect of which the warrant is issued is covered by amnesty in the executing Member State, and that Member State has jurisdiction to prosecute the offence in accordance with its criminal law), ne bis in idem (if the executing judicial authority has been notified that the requested person has been finally convicted in respect of the same offence in another Member State, subject to the condition that, where there has been sentence, the sentence has been served, or is in the process of being served, or may no longer be executed under the law of the sentencing Member State), and the age of the requested person (if the person who is the subject of the European arrest warrant may not, owing to his age, be held criminally responsible for the acts on which the arrest warrant is based under the law 
Grounds for non-execution of the EAW are listed in Article 20 of AJCCM-EU after paragraph 1 which begins: "In addition to to the offences from Article 10 hereof,..." Given that Article 10 expressly lists 32 categories of offence in respect of which double criminality is not verified, from the wording of the Act it follows that the existence or otherwise of the grounds for non-execution of the EAW are not to be ascertained where offences listed in Article 10 of AJCCM-EU are involved.

In case Kž-eun 23/17 of 7 September 2017 involving verification of double criminality, the Supreme Court of the Republic of Croatia had this to say:

"Furthermore, the appellant himself does not dispute that the European arrest warrant was issued in respect of one of the offences listed in Article 10 AJCCMEU (accessoryship - aiding homicide). This means that the domestic court, as the court responsible for executing the EAW, does not verify the criminality of the charged offence under domestic law, and the cited provision of AJCCM-EU is in accordance with Article 2(2) of the Council Framework Decision on the European arrest warrant and the surrender procedures between Member States of 13 June $2002(2002 / 584 / \mathrm{JHA})$. Therefore, given that in the case at hand the arrest warrant was issued for the purpose of executing a custodial sentence passed for one of the offences listed under Article 10 of AJCCM-EU, for which an EAW is executed without verification of double criminality, the first-instance court correctly concluded that the statute of limitation is not to be verified against the domestic legislation either - a standpoint expressed in a number of decisions of this Court (Kž-eun-7/14, Kž-eun-8/14), which makes it unnecessary to consider other objections raised by the appellant concerning the calculation of the time when the execution of the sentence became statute-barred."

The same is apparent from the decision of the Supreme Court of the Republic of Croatia in case No. Kž-eun 3/17-4 of 24 January 2017:

"Namely, the subject of the European arrest warrant in this case is forgery, a criminal offence listed among the offences covered by Article 10 of AJCCM-EU, i.e. offences for which there is no verification of double criminality. Verification of double criminality is ruled out where any punishable conduct referred to in Article 10 of AJCCM-EU is involved.

According to the established case law (Kž-eun 2/14 of 17 January 2014, Kž-eun 5/14 and Kž-eun 14/14 of 6 March 2014), and pursuant to the legal opinion ex-

of the executing State). Other grounds for non-execution are indicated in the Framework Decision as optional grounds for non-execution of the warrant 
pressed by the Criminal Division of the Supreme Court of the Republic of Croatia in Su-IV k-21/16.-11, verification of double criminality is ruled out in the instant case. The latter includes a prohition on verifying whether criminal prosecution has become statute-barred, because the statute of limitation is a component of the notion of double criminality.

This case law and legal opinion should also be applied, mutatis mutandis, in respect of ne bis in idem. In other words, there is no verification of whether the requested person has already been finally convicted of the same offence in another Member State, provided that the criminal sanction has been executed, or is in the process of being executed, or may no longer be executed under the law of the country in which the relevant judgment was given (Article 20(2)(2) of AJCCM$\mathrm{EU})$. This ground for refusing execution of the European arrest warrant is placed in the same provision as the expiry of the statute of limitations (Article 20(2)(7) of AJCCM-EU). Neither of the grounds referred to in the cited provision of Article 20(2) AJCCM-EU are verified where the subject of the European arrest warrant is punishable conduct listed under Article 10 of AJCCM-EU, which is exactly the case here."

\section{SUBSEQUENT CONSENT}

In cases where the requested person has been surrendered under the European arrest warrant, and in the issuing State or another country another criminal proceeding is pending or there is a final judgment whereby a custodial sentence was imposed, which was not encompassed by the warrant and consequently not by the surrender order, then there is the possibility of a subsequent consent to conducting proceedings or executing the custodial sentence. In that procedure, grounds for refusal of the execution of the European arrest warrant envisaged by Articles 20 and 21 of AJCCM-EU are assessed, and if mandatory or optional grounds for non-execution are found to exist, then consent is to be denied, as is apparent from decision No. Kž-eun 20/16-4 rendered by the Supreme Court of the Republic of Croatia on 9 May 2016:

"In the procedure involving consent within the meaning of Article 41 AJCCMEU, the first-instance court found that all statutory requirements had been met for consent to be given, and did not find any grounds for mandatory refusal as provided for in Article 20(2) of AJCCM-EU, nor any grounds for optional refusal provided for in Article 21 thereof.

Having regard to the principle of mutual recognition between EU Member States as provided in Article 3 of AJCCM-EU and the rpinciple of effective cooperation 
as provided in Article 4 thereof, the first-instance court acted correctly in giving consent for the Republic of Poland to conduct criminal proceedings against the requested person J. A. P. for offences committed prior to the surrender but not contained in the European arrest warrant."

Pursuant to Article 41 of AJCCM-EU, consent is given by the court that made the order for the concerned person to be surrendered under the European arrest warrant. The court must make that decision within 30 days of receiving the request, without prior examination of the person.

Consent may be given for:

a) conducting criminal proceedings against or executing a custodial sentence or a sanction involving detention of the surrendered person for an offence non covered by the warrant but committed before surrender,

b) surrendering the person to another Member State for an offence committed before surrender,

c) surrendering the person to a third country for an offence committed before surrender. ${ }^{14}$

No appeal lies against the consent order, as is apparent from the decision of the Supreme Court of the Republic of Croatia No. Kž-eun 32/16-4 of 12 September 2016:

"Pursuant to Article 491(1) of the Criminal Procedure Act (Official Gazette, No. 152/08, 76/09, 80/11, 91/12 - Constitutional Court decisions 143/12, 56/13, 145/13 i 152/14; hereafter: CPA/08), an appeal against an order of the state attorney, pre-trial judge, or any other first-instance court decision, may always be brought by any party or person whose rights have been violated, unless CPA provides that no appeal is allowed. The Act on Judicial Cooperation in Criminal Matters with EU Member States is indisputably a lex specialis governing the application of the instruments of cooperation in criminal matters between the competent domestic judicial authorities and the competent judicial authorities of other EU Member States expressly listed therein, and Article 41 of that Act, entitled „Consent giving procedure", in paragraph 3 provides that no appeal shall lie against a decision rendered in that procedure. The cited provision is of a cogent nature and does not envisage any exceptions, which makes it obvious that the appeal is not allowed, notwithstanding the fact that the County Court of Split in the notice of the right to appeal ending the contested order stated that it was allowed, seen that

14 Article 41 of AJCCM-EU 
an erroneous notice of the court may not confer a right that is not conferred by the statute."

\section{TIME LIMITS FOR THE DECISION TO EXECUTE EAW AND REMEDIES}

The procedure and the time limits for executing the European arrest warrant depend on the statement by the requested person on whether or not they consent to surrender. Where the state attorney has filed a motion for pre-trial detention of the requested person in order to secure execution of the European arrest warrant, the requested person may, at the hearing held to decide on pre-trial detention, give consent to surrender, in which case the pre-trial judge shall, alongside the detention order, also make a surrender order within three days from consent. The order shall be served on the requested person, their defence council, and the state attorney, who shall have three days to file appeals, and the decision on an appeal against the order made by the pre-trial judge shall be rendered by the pre-trial panel within three days.

In the event that the state attorney has not filed a motion for detaining the requested person, or the requested person has not consented to surrender before the pre-trial judge, the surrender order shall be made by the pre-trial panel. Where the requested person has, at the hearing, consented to surrender, the pre-trial panel must also without delay, within three days from consent at the latest, make an order allowing surrender, unless there are grounds for non-execution of the European arrest warrant as prescribed by Articles 20 and 21 of AJCCM-EU, and appeal against the order of the pre-trial panel lies to a higher court panel which has three days to decide on it. Consent shall be entered in the record which shall be drafted in the way that makes it indisputably apparent that, in giving consent, the requested person acted voluntarily and was fully aware of the consequences thereof, and consent and renunciation of entitlement to the speciality rule are irrevocable.

Although the state attorney questions the requested person prior to the procedure before the court and must inform him or her of the possibility of consenting to be surrendered to the issuing State, whereby the consent statement is entered in the record, such a statement has no legal effect, as is apparent from the reasons for decision Kž-eun 2/2018-4 delivered by the Supreme Court of the Republic of Croatia on 13 February 2018:

"Namely, pursuant to the provisions of AJCCM-EU, the requested person may give consent to surrender only before the pre-trial judge or the pre-trial panel of 
the competent court. Such an interpretation follows from Articles 24.a.(4) and 24.b.(6) of AJCCM-EU, which expressly provide that the requested person may give consent to surrender either before the pre-trial judge (where there is a hearing scheduled to decide on pre-trial detention at the motion of the state attorney) or before the pre-trial panel (both in the situation where no hearing was held before the pre-trial judge and where such a hearing was held but the requested person did not consent to surrender). Furthermore, under Article 27(4) and 28(1) of AJCCM-EU the court is under a duty to, within the prescribed time limits, inform the competent authority that issued the European arrest warrant about the requested person's consent. In order for the time limit to be met, it is logical that the consent to surrender must be given in court, because time starts running from the date consent is given. Admittedly, pursuant to Article 24(2) of AJCCM-EU, the state attorney is under a duty to, before questioning the requested person, read them the Letter of Rights, i.e., put them on notice of the rights they enjoy under the domestic rules of criminal procedure and, pusuant to Article 24(3) of AJCCM-EU, inform them about the contents of and the basis for issuing the European arrest warrant, the possibility of consenting to surrender to the issuing country, and the possibility of renouncing the entitlement to the speciality principle and the consequences of the renunciation statement within the meaning of Article 38(1) of AJCCM-EU. It follows that the state attorney's powers in respect of consent to surrender and renunciation of the speciality rule do not go beyond informing the requested person about the contents of those rights and the consequences thereof. The authority competent to receive the requested person's consent statement, and the statement on renunciation of the entitlement to the speaciality rule, is the court, which makes sense in view of the fact that, in the surrender procedure, the state attorney assumes a double role: on the one hand he represents the foreign country that issued the European arrest warrant, and on the other hand he or she conducts certain preparatory activities towards instituting the EAW execution procedure, i.e., activities which mutatis mutandis correspnd to the state attorney's role and powers at the criminal investigation stage. It follows that the consent to surrender given by the requested person in the course of being questioned by the state attorney is not validly given and may consequently not produce any legal effects."

Where the requested person opposes surrender, the pre-trial panel shall question him or her about the reasons for opposing it. The competent state attorney may, and the person's defence council must attend the hearing. The requested person, their defence council, and the state attorney are given three days to appeal against the order of the pre-trial panel, and appeals are heard, within three days, by the 
pre-trial panel of a higher court. In the latter case, a decision on surrender of the requested person must be made within 60 days from arrest or first interrogation.

With regard to the possibility of filing a second appeal against a surrender order, the Supreme Court of the Republic of Croatia, in reasons for its decision No. Kžeun $7 / 17$ of 6 February 2017, had this to say:

"In this appeal, the requested person repeats at length the grounds for which he moves for a new procedure on the execution of the European arrest warrant and surrender of the requested person V. Č. R. to Italy, which surrender was granted by the final order of the County Court of Vukovar, No. Kv-eun-12/16 of 21 April 2016, but was adjourned until the final conclusion of criminal proceedings pending before the County Court of Rijeka against V.Č. on charges of having committed the offence referred to in Article 173(3) of the Penal Code (Official Gazette, No. 110/97, 27/98 - correction, 50/00, 129/00, 51/01, 111/03, 190/03, 105/04, 84/05 - correction, 71/06, 110/07, 152/08, 57/11 and 77/11; hereafter: PC/97), and the outcome of those proceedings in respect of the requested person is uncertain because the other defendants are absconding. As regards the admissibility of his application for a new procedure, the appellant submits that „the court failed to comply with Article 132 of AJCCM-EU which provides for the application of other statutes, including the Penal Code, in situations such as the one at hand, i.e. where a particular issue is not regulated by AJCCM-EU.

However, in denying the requested person's motion for a new procedure for the execution of the European arrest warrant and the person's surrender to the Republic of Italy, the first-instance court correctly pointed out that the provision of Article 501(1)(3) of CPA/08, which the requested person invokes in his application, may not be applied in the instant procedure because it pertains to criminal proceedings concluded with a final judgment, nor is there room for it to be applied analogously to the procedure for the execution of the European arrest warrant given that, pursuant to that provision, „new facts“ must be „such as to be conducive to an acquittal of a convicted person or to their being convicted under a more lenient penal law", and the procedure for the execution of a European arrest warrant is not designed to decide on a defendant's conviction or acquittal, but rather on the fulfillment of the strictly prescribed formal procedural requirements for surrender as set out in the relevant provisions of AJCCM-EU, whose existence is established in a procedure conducted in accordance with AJCCM-EU, and subsidiary application of CPA/08, prescribed under Article 132 of AJCCM-EU, is an option only where it is possible by the nature of things, which is not the case with respect to the provisions on criminal retrial. 


\section{CONCLUSION}

" $\$ 25$ It should be recalled, as a preliminary point, that the purpose of the Framework Decision, as is apparent in particular from Article 1(1) and (2) thereof and recitals 5 and 7 in the preamble thereto, is to replace the multilateral system of extradition based on the European Convention on Extradition of 13 December 1957 with a system of surrender between judicial authorities of convicted or suspected persons for the purpose of enforcing judgments or of conducting prosecutions, that system of surrender being based on the principle of mutual recognition (judgment of 5 April 2016, Aranyosi and Căldăraru, C-404/15 and C-659/15 PPU, EU:C:2016:198, para 75 and the cited case law).

$\$ 26$ The Framework Decision thus seeks, by the establishment of a new simplified and more effective system for the surrender of persons convicted or suspected of having infringed criminal law, to facilitate and accelerate judicial cooperation with a view to contributing to the objective set for the European Union to become an area of freedom, security and justice, founded on the high level of confidence which should exist between the Member States (judgment of 5 April 2016, Aranyosi and Căldăraru, C-404/15 and C-659/15 PPU, EU:C:2016:198, para 76, and the cited case law).

$\$ 27$ Both the principle of mutual trust between the Member States and the principle of mutual recognition are, in EU law, of fundamental importance given that they allow an area without internal borders to be created and maintained. More specifically, the principle of mutual trust requires, particularly with regard to the area of freedom, security and justice, each of those States, save in exceptional circumstances, to consider all the other Member States to be complying with EU law and particularly with the fundamental rights recognised by EU law (judgment of 5 April 2016, Aranyosi and Căldăraru, C-404/15 and C 659/15 PPU, EU:C:2016:198, para 78, and the case law cited).

$\$ 28$ The principle of mutual recognition, which pursuant to Article 1(2) of the Framework Decision constitutes the 'cornerstone' of judicial cooperation in criminal matters, means that the Member States are in principle obliged to execute the European arrest warrant. It follows that the executing judicial authority may refuse to execute such a warrant only in the cases, exhaustively listed, of obligatory non-execution, laid down in Article 3 of the Framework Decision, or of optional non-execution, laid down in Articles 4 and $4 \mathrm{a}$ of the Framework Decision. Moreover, the execution of the European arrest warrant may be made subject only to one of the conditions exhaustively laid down in Article 5 of that Framework Deci- 
sion (judgment of 5 April 2016, Aranyosi and Căldăraru, C-404/15 and C-659/15 PPU, EU:C:2016:198, paras 79 and 80 and the case law cited). "15

\section{REFERENCES}

\section{BOOKS AND ARTICLES}

1. Krapac, D., Framework Decision of the Council [of the European Union] of 13 June 2002 on the European (EUN) and the surrender procedures between Member States (2002/584/JHA), Collected Papers of the Law Faculty of Zagreb, 64(5-6)

2. Turudić, I., Pavelin Borzić, T., Bujas, I. Impact of the Framework Decision on the European Arrest Warrant on the Constitutional Order of the Member States (1st part), Novi informator, No. 6285/2014

3. Turudić, I., Pavelin Borzić, T., Bujas, I., European arrest warrant with examples from case law, Novi Informator, Zagreb, 2014

4. Turudić, I., Pavelin Borzić, T., Bujas, I., Relationship Between the Principles of Mutual Recognition/Confidence and Verification of Double Criminality, Collected Papers of the Law Faculty of the University of Rijeka, 36(2)

\section{COURT OF JUSTICE OF THE EUROPEAN UNION}

1. Case C-477/16 Openbaar Ministerie v Ruslanas Kovalkovas [2016] OJ C 14

2. Case C-463/15 Openbaar Ministerie v. A. [2015] OJ C 38

3. Case C-168/13 Jeremy F. v Premier ministre [2013] OJ C 156

\section{EU LAW}

1. Council Framework Decision 2002/584/JHA on the European arrest warrant $\mathrm{t}$ and the surrender procedures between Member States [2002] OJ L 190/1

\section{LIST OF NATIONAL REGULATIONS, ACTS AND COURT DECISIONS}

1. Criminal Procedure Act (Official Gazette, No. 152/08, 76/09, 80/11, 91/12 - Constitutional Court decisions 143/12, 56/13, 145/13 i 152/14)

2. Act on Judicial Cooperation in Criminal Matters with Member States of the European Union ( Official Gazette, No. 91/10, 81/13, 124/13, 26/15, 102/17)

3. decision of the Constitutional Court of the Republic of Croatia, No. U-III-351/2014 of the of 24 January 2014

4. decision of the Supreme Court of the Republic of Croatia No. Ǩ̌z-eun 7/17 of 6 February 2017

15 Case C-477/16 Openbaar Ministerie v Ruslanas Kovalkovas [2016] OJ C 14, par. 25-28 
5. decision of the Supreme Court of the Republic of Croatia No. Kž-eun 32/16-4 of 12 September 2016

6. decision of the Supreme Court of the Republic of Croatia No. Kž-eun 20/16-4 rendered by on 9 May 2016

7. decision of the Supreme Court of the Republic of Croatia in case No. Kž-eun 3/17-4 of 24 January 2017

8. decision of the Supreme Court of the Republic of Croatia No. Kž-eun 12/17 of the of 7 March 2017

9. decision of the Supreme Court of the Republic of Croatia No. Kž-eun 23/17 of 7 September 2017

10. decision the Supreme Court of the Republic of Croatia No. Kž-eun 22/17 of 31 August 2017

11. decision of the Supreme Court of the Republic of Croatia No. Kž-eun-5/14 of 6 March 2014

12. decision of the Supreme Court of the Republic of Croatia No. Kž-eun 2/18-4 of 13 February 2018

\section{WEB REFERENCES}

1. [www.ejtn.eu/.../THEMIS\%20written\%20paper\%20-\%20Romania..] Accessed 1 March 2018 